\title{
UNMIXED PLEASURE AND INWARD DOUBTS
}

\author{
Peter Lewis
}

I am temperamentally one of those who, in acknowledging the inspiration and influences of others, is forced into a recognition of my own poor efforts.

This has been a year when, for me, self doubt grew swiftly like penicillin in a laboratory mould. Incubation started when I read an exiting, though somewhat eccentric, book on collecting and collectors, intriguingly subtitled "An Unruly Passion».'

The author argued that people collect things, from train tickets to teddy bears, from porcelain to pictures, from high art to low stories, as a reaction against the insecurities of life. All collectors and classifiers, he opined, were driven less by a love of artefacts, than by the need to compensate for the bleakness of their childhoods. Ouch! My self esteem was further bruised when a well respected speaker, at the Annual Conference of the Museums Association of Great Britain proclaimed that curators "only do what they do because they're accustomed to doing it!» «Social Historians» he continued «are human beings who don't feel at home with society or with other people.» ${ }^{2}$ I snapped tetchily at both these judgements with the rash annoyance of a basking fish at an artificial fly and became securely hooked. Both barbs bit deep. I began to wonder. Why do curators do what they do? Are we driven by a definable sense of academic mission or are we confused souls twisted by strange mother fixations?
The origins of most museums are well documented. They are usually inseparable from their originators. My distinguished predecessor, Frank Atkinson, the founding director of Beamish, records, that in 1953, he first saw in Europe an open air museum. "They tend, over there", he wrote "to call them Folk Museums ... I was most impressed by the Lillehammer museum in Central Norway and decided that we really ought to have something like that in England. ${ }^{3}$ It took him nearly twenty years of advocacy to convince the political authorities and communities of Northern England that he was right. His arguments fell first on deaf or disbelieving ears. One newspaper asked why the region was being compelled "to endure the largest junk yard in Europen. ${ }^{4}$ This sort of thing, it was suggested, like saunas, gravadlax and free love, might be acceptable to the Swedes, Danes and Norwegians those peculiar peoples - but not to the sensible English! Decades later the North of England is astonishingly proud of 


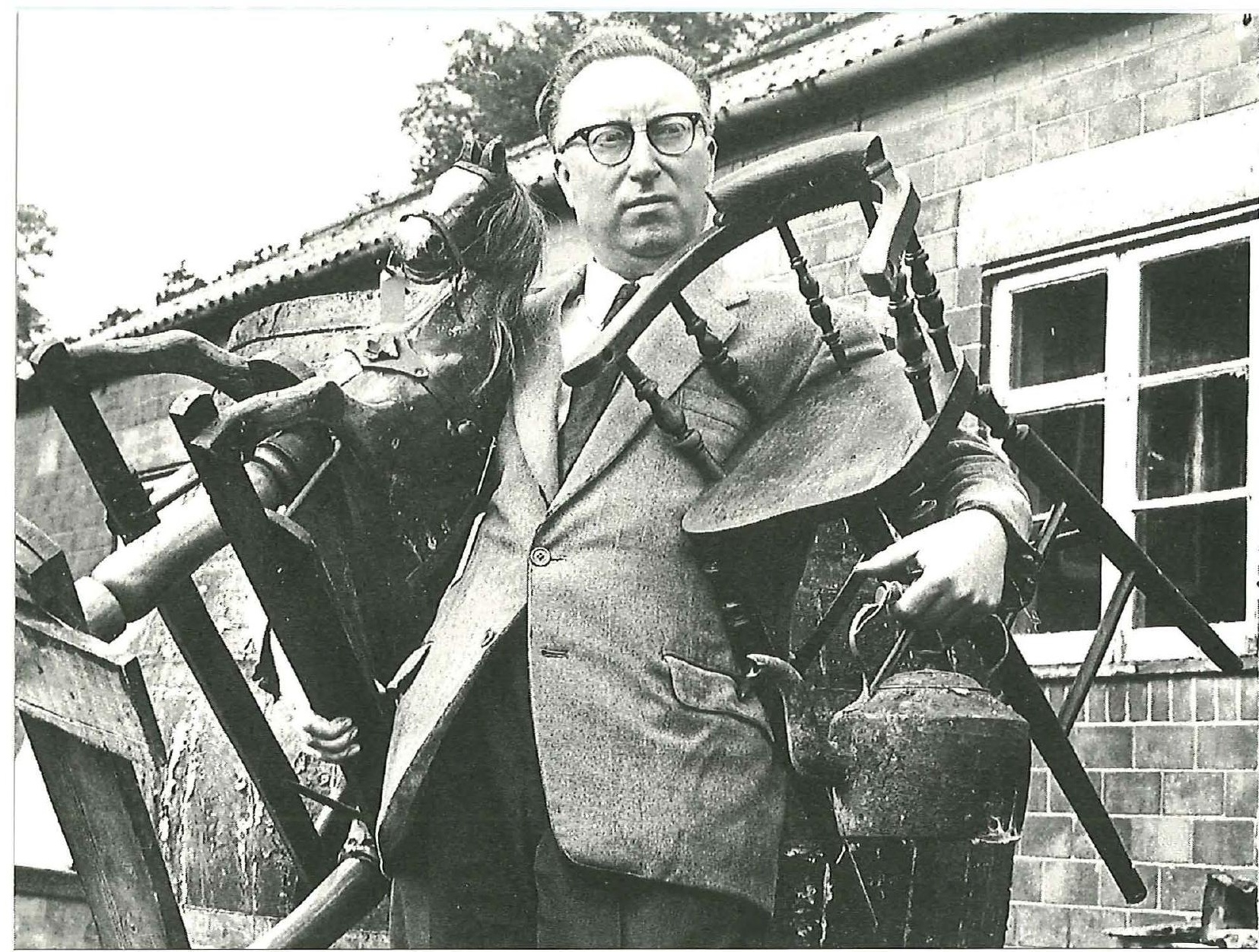

Frank Atkinson in collecting mood'. Photo by Regional Resource Centre Photographic Library. Beamish, The North of England Open Air Museum.

Beamish though the region's appreciation is more obviously moral rather than monetary. "There's no praise» as Molière reminds us, "to beat the sort you can put in your pocket». ${ }^{5}$ In its first quarter century Beamish has developed swiftly in a characteristically English way. Frank Atkinson's aims and aspirations were, in the 1950 s, similar to those expressed in Norway more than fifty years earlier. Then Anders Sandvig defined his mission thus: -

It is to be a collection of homes, where one can almost meet the people who lived there, understand their way of life, their taste, their work ... it is not just individuals who are reflected but a whole family, generation after generation ... I will provide a full-scale illustration of a settlement as a united whole - not just the big farm with its many buildings and treasured family possession, but the home of the small farmer and the cotter, the village craftsman's workshop ... and the mountain pasture huts far up in the woods. And from its site up on the hill the old village church ... shall sound its bells in requiem over the generations that have passed away. ${ }^{6}$

Sandvig spoke with unashamed emotion and a sense of theatricality. Frank Atkinson was equally insistent and equally passionate. His museum would serve "to illustrate vividly the way of life, the institutions, customs and material equipment of the ordinary people» and would "attempt to make the history of a region liven. ${ }^{7}$ The key words in his statement were vividly and live. He did not follow conventional 
museum practice, recognising that many institutions were little more than classified storehouses of the raw materials of history. The achievement of Frank Atkinson was to use facts and objects to tell a coherent and intelligible narrative. Though inspired by Lillehammer and influenced by Skansen and other Nordic institutions, Beamish was very different; recognisably a member of the same family but resolutely distinct. There was, and still remains, in Britain a belief that a 'folk-life museum' is concerned with the age of the horse and cart. This is a matter of vocabulary. In the languages of Northern Europe folk or volk is neutral, referring to people. For Hazelius and others folk-life is simply 'the life of the people'. In English folk is a mildly pejorative word. Folk-song, folk-dance and folk-art all have a faintly ridiculous air in English, redolent of Merrie England. It has more to do with maypoles than modernity. Beamish was to record neither medieval history nor the rural past of far-gone centuries, but life that had only just passed. The great temptation of all museums, including the open air genre, is romanticism. As we move buildings and transfer artefacts they can be cleaned, tidied and repaired in such a way that the associations, that they once had for those who used and lived in them, may become sanitised. There is in our Merrie Englands, Merrie Swedens, or Brothers' Grimm Theme Parks, nothing disagreeable, nothing dirty, nothing damaged. As historians we can achieve authenticity but have we done so by sacrificing realism? The second danger is that open air museums, especially in mainland Europe, tell the lives of predominantly rural people. Urban life, manufacturing and commerce are rarely represented. It may well be that rural life likely, that small wooden buildings are easier and cheaper to move and re-erect than larger structures of brick, stone and masonry. The North of England does have an important rural heritage but it has been for two centuries one of Britain's major industrial areas. Beamish had to confront this challenge. It had to become, as Frank Atkinson declared «a museum dealing much more in social history than folk-life..1 ${ }^{8}$

In the judgement of the itinerant museum critic, Kenneth Hudson, Beamish succeeded. It was not «in the slightest degree folksy». In his book Museums of Influence, he listed some 37 pioneers in museum development from 13 countries. Beamish was one of that proud pantheon, chosen, as the author explained, because they had "broken new ground in such an original or striking way that other museums have felt disposed or compelled to follow their example». "Mere novelty" was not sufficient. Each museum must have shown "significant and worthwhile orginality" and to have demonstrated "a real social need»." It was a well deserved tribute to Frank Atkinson and to the colleagues who had made tangible his original dream. As he retired in 1987, Beamish was awarded both the British and European Museum of the Year Awards in successive years.

The museum that Frank Atkinson left for his successors was wonderful but incomplete. He had been driven by a sense of urgency, believing that local culture, "customs, traditions and ways of speech" were dying out at so rapid a rate that «it is now almost too late ... it is essential that 
PETER LEWIS

130 collecting be carried out quickly and on as big a scale as possible." In his yet-to-be published biography, he explains that he "wanted the collection to be fully representative" of communities about which he «knew very little». Ideally, he and his colleagues, would have wished to spend «five or more years researching" and "analysing ways of life ... establishing a balanced collecting policy.» ${ }^{10}$ This was unattainable for reasons both pragmatic and political. The museum adopted a "you offer, we'll collect it” principle. Intellectually this was less haphazard, more rigorous, than it might first appear. It produced better collections, unimpaired by curatorial pre-conceptions. Beamish, thus, avoided the accusation that objects had been collected to fit an already determined editorial line. Instead, things themselves dictated and modified the narrative. As a result the museum possesses vast, important and badly housed collections. Problems of storage and care will remain for many years but the alternative would have been the total loss of many artefacts. Our present collections policy is little changed. We do demur at accepting yet more sewing machines, typewriters or mangles but otherwise we are as hungry as ever.

As we approach the end of the twentieth-century Beamish remains unfinished. We are perhaps only 5\% complete and in due course even these areas will be changed. For the first 25 years of its history Beamish had only one time slot. Exhibits were variously dated from 1880 through to the $1920 \mathrm{~s}$. Wishing to sharpen comparisons between the Town, the Colliery Village and the Farm, we moved to an agreed date of 1913. If you wish to tell the story of early twentieth-century life you must be pre-war, in-war, or post-war. Most of our period areas are set in this time slot. We will continue to develop. In the Town we are constructing a bank, a large fountain and have plans for a chemist's shop, bakery and covered glass shopping arcade. I dream that my own memorial might be a traditional town museum with the water colors, birds eggs and mahogany cases of earlier collections. A museum within a museum is a Chinesebox concept that appeals to my eccentric sense of style.

In 1995 Beamish started to develop a different area; an earlier historical time. Pockerley Manor Farm is shown as it was in the 1820s. This decade is an important one for our regional history, marking the coming of the railways and developments in mining and engineering. Our two dates represent the beginning of traditional industries and the point at which they started to decline. In choosing these dates we have made life difficult for ourselves but, we believe, more interesting and challenging for our visitors. As they stand on the terrace of the house of an affluent middle class farming family, they will see, smell and hear, in the valley below, the coming of the railways. An intellectual idea is being reinforced by a tangible metaphor, a sensation intended to help visitors understand themselves in time. In future years we will develop and exhibit the flint mills and forges whose remains lie hidden under a deceptively green Arcadia.

We are not only developing sites but also the ways in which we interpret them. In earlier decades Beamish attempted to avoid controversy. We need now to say more about politics, trade unionism, the 
role of women in society, and a whole host of other challenges. We are not, however, a museum of labels or information panels. Once we have filled our buildings, all we wish to explain or to provoke must be done through people. We once used demonstrators and museum guides in a very conservative way. Our attendants were there less "to help visitors" than "to stop the visitors helping themselves". In the directorial 'inter-regnum' between Frank Atkinson and myself, the use of costumed interpreters was introduced. People, however well trained, are obviously more dangerously variable than information boards. A label is for ever; an actor is for now and that now will be different for each visitor. In the previous museum in which I was involved, at Wigan Pier in Lancashire, I used, inside an old warehouse building, a group of professional actors. Their work was performed in costume in the first person. They found the work exhausting but exhilarating as, hopefully, did their audiences. I have not created a similar acting company at Beamish. The very nature of an open air museum, varied sites scattered over a landscape of some 200 hectares, does not allow that same dramatic intensity. The interpretative staff of Beamish are local people, with their own experiences and speech patterns, trained to transmit their cultural histories. They are instructed, supported and monitored by a Keeper of Interpretation, himself a distinguished curator, who with his supervisory staff, is responsible for creating performances on a seven-day-a-week, fifty-two weeks a year rota. As a dramatic entity this is more difficult to achieve than any endeavour in the professional theatre.

Were I a dictator, which unhappily I am not, I would insist that our amateur, but the first person. My senior staff have consistently argued against this technique. Reluctantly I have conceded. The Director in a theatre or a museum may believe himself to be God but he or she soon realises that actors and curators are usually atheists! Thus, interpreters at Beamish speak in both the first and the third person. They respond to the voice of the visitor. If asked where the lavatories or restaurants are located they will not feign an antique surprise but concisely give the information. An interpreter dressed as a collier's wife may well say "I am doing this» or instead "a housewife in 1913 would have done it this wayn. It is a matter of making communication with visitors the most natural in order that understanding flows more easily.

It would be naive to believe that our style is totally approved by advocates of conventional museum techniques either in Britain or abroad. Some critics assume that education is incompatible with entertainment. They suggest that any museum in such a remote area as Beamish must be sacrificing professional integrity for the popularity exemplified by half a million visitors a year. I would deny this. Some of my highly respected colleagues in open air museums on the European mainland look askance at British, and to some extent, Scandinavian and Dutch techniques. They believe our methods to be romantic, transatlantic and sentimental. So be it! I wish them well. I greatly admire the Germanic, Eastern European tradition which places more emphasis upon buildings than on people. This is a valid academic aim. I am content for them to show the where, what, 
132 how and when of buildings. I am more concerned to show the who of those who used such buildings. In this I am pleased to be seen as a theatrical director rather than as an architectural zoo-keeper.

What inspiration or influence has made me behave in this way? In honesty I am neither an heir of Hazelius nor an acolyte of Atkinson. I suspect that I am inescapably a product of my childhood. I was born in a working class area of London in 1938. Socially we lived "on the other side of the park", "on the wrong side of the railway tracks». My grandparents and uncles were dockers, factory workers, railwaymen, soldiers and merchant seamen. My grandmothers were housewifes and parttime factory workers. My father was first a stonemason, then a welder on the Underground. My mother worked in a machine knitting factory, then, after my birth, in a factory making condoms. Her working life was dedicated to funding an education which would enable me to escape working class toil. At the time I resisted her aspirations fearing that I would end up in a limbo of non-belonging, but she had her way. I was educated out of the slum by the resolve of my parents and the tenacity of my teachers.

For some of my contemporaries there was no looking back. They escaped into an academic life of respectable literature or high art and embraced willingly more bourgeois or establishment roles. Less strong-minded I have never been able to shed my working-class origins. I remain an unredeemably born-again leveller or digger. " Thus, when in late middle age, with a background of working in retailing and theatre, I was offered a chance to direct a museum I did not falter. It was a chance, however poorly paid, to research my roots and to articulate my heritage. When I was a boy I was taught a great deal of history both at primary and secondary school. I remember those lessons well. We were told stories of kings and conquerors, of princes and prime ministers. We studied the great, the good and the not-so-good, who were usually foreigners. In earlier times common folk, like my unknown ancestors, revolted and were efficiently put down by those above them. Later the peasantry became the growing labouring classes on whose backs national wealth was created. History, it seems, was written from the top downwards. It was the record of the privileged named few rather than of the unprivileged and anonymous many.

Over my lifetime the study of history has changed significantly. There is now much more history written from the bottom upwards. Scholarship digs deep; the amount of source material has increased. Thanks to computer technology there has never been so much history available. Ironically, less and less history reaches the general public. The systematic teaching of history has, thanks to the demands of the National Curriculum, all but disappeared from British schools. A large majority of people absorb their knowledge of the past from the costume dramas of cinema and television screens or from historical novels and bodice-ripping romances. Does this matter?

I believe it does. There has never been a greater need for real history. We live in a world of rapidly increasing change. My father was a teenager when he saw his first fragile aircraft. He lived to see men start the exploration of the planets. In times of 
accelerating change people and communities seek their roots. There are some commentators who would have us believe that an interest in history and museums, what they call 'an obsession with the past' is a symptom of decline. I would deny this. Both old and young people, old and young nations, have a deep need to understand their past. The way we are and the way we will be are directly influenced by the way we were. It is perhaps a cliche to opine that history never seems like history when you are living through it. It feels both confusing and uncomfortable. Looking back it is possible to discern a shape. If Beamish were a sermon and I was asked to define the text it would be "Today could have been better. Things might have developed differently". There is, I believe, no sense in studying the past if we don't use that knowledge in an attempt to improve the present and shape the future.

Academics and journalists in Britain have been very critical of this approach. They query both the ends and the means of such aspirations. Museums, they agree, should be «somewhat neutral ... facilities for the presentation of individual acts of creation". ${ }^{12}$ I would deny this with all my strength. Neither neutrality nor blandness is the correct stance of a museum, theatre, opera house, concert hall, art gallery or cinema. Museums don't have to be alike in style or methods. They can be different. They can even be vulgar, dangerous or provocative. I am attracted to Erik Hofrén and his hopes for Norrköping. He sought and seeks, I read, to tell "history from below» to create "a museum from below». He asserts that the Museum of Work will become a cheeky voice in the political and cultural landscape of Sweden ... it has to be a people's high school, a research institute, a place of meeting and, why not, a place of joy as well! For far too many people history is a black hole sometimes called museum. Let us change this and bring light to black holes! ${ }^{13}$

As I attempted to write this essay I received a query from a local university student asking me which was the first open air museum in the world. My initial response was «who cares?!» My second was to suggest Skansen till I remembered reading learned pleas from Norwegian scholars that institutions in their country predated the estate of Hazelius. Then I recalled hearing a very learned lecture from the most serious of all German scholars proving that Marie Antoinette's farm buildings, the Petit Trianon, had prior claims of progeniture. I think the argument was a serious one but one never knows with German scholarship! My eventual reply was, I suspect of no use to my enquiring student. Cynically and blasphemously I suggested that the Garden of Eden was the first and most influential of all open air museums. It was created by someone who, claiming to be God, named and labelled all the exhibits. Some had a notice insisting DO NOT TOUCH! When that instruction was disobeyed the museum attendants, Adam and Eve, were evicted and the museum closed earlier than expected. The agents who drove away our human ancestors were avenging angels with swords. I note that the word angel means messenger, or a passer on of truth. Is it too fanciful to imagine the best of modern museum people as angels encouraging people back into Paradise? 
PETER LEWIS

134

NOTES

1. I regret I have lost both the book and the reference to this author.

2. Mark O'Niell, Museums Association

Conference, Leicester, September 1995.

3. Frank Atkinson, Friends of Beamish Newsletter,

Summer 1995.

4. Newcastle Journal, 1969.

5. Molière, The Would-be Gentleman, 1670.

6. Anders Sandvig, quoted in preface of The Sandvig Collections Guidebook (ed Fartein ValenSenstad) 1986.

7. Frank Atkinson, Policy for a Regional Open-Air Museums, Working Party Report 1966.

8. Frank Atkinson, «New Open-Air Museums», Museum, Vol.XXIII, No.2, 1970/71.

9. Kenneth Hudson, Museums of Influence 1987. Chapter 6 and 7 of this book deal i greater depth with the distinctions between folk-life, social history and industrial archeology.

10. Frank Atkinson, Friends of Beamish Newsletter, Summer 1995.

11. Levellers and Diggers were radical seventeenthcentury English groups which advocated communal ownership of land, freedom of worship and republicanism etc.

12. Robert Hewison, The Heritage Industry, 1987.

13. Erik Hofrén/Maths Isacson, Museum from below - history from below.

Peter Lewis is the director of Beamish, the North of England Open Air Museum.

Adr: Beamish, County Durham DH9 ORG, United

Kingdom

Fax +44-1207290933 